Makale türü / Article type: Araştırma / Research

\title{
Zaman Yönetimi ve Akademik Başarı İlişkisi: Artvin Çoruh Üniversitesi, Hopa İktisadi ve İdari Bilimler Fakültesinde Bir Uygulama \\ ****
}

\section{Time Management and Academic Success Relationship: An Application in the Artvin Çoruh University, Hopa Faculty of Economics and Administrative Sciences}

\author{
Dr. Öğr. Üyesi Özgür DOĞAN \\ Artvin Çoruh Üniversitesi, Hopa İ̈BF, ozgurdgn@artvin.edu.tr
}

\section{Özet}

Bu çalışmada öncelikle zaman kavramı ve onunla ilişkili diğer kavramlar ele alınmış, zamanın etkin kullanımının başarıyı arttıracağından hareketle, öğrencilerin zaman yönetimi ve akademik başarıları arasındaki ilişki incelenmiştir. Çalışmanın temel amacı zaman yönetimi ve onun alt faktörleri ile öğrencilerin akademik başarıları arasındaki ilişkinin olup olmadığını belirlemektir. Bunun için Artvin Çoruh Üniversitesi, Hopa İİBF'de eğitim gören 275 öğrenciden oluşan bir örneklem üzerinde çalışma yürütülmüştür. Araştırma sonucunda, zaman yönetimi ve onun alt faktörlerinin, düşük bir düzeyde de olsa, akademik başarı ile ilişkili oldukları ve aynı zamanda akademik başarıyı etkiledikleri bulgusuna ulaşılmıştır.

Anahtar Kelimeler: Zaman, Zaman yönetimi, Akademik başarı

Jel Sınıflandırması: M10, M19

\begin{abstract}
In this study, firstly the concept of time and other concepts related to it were discussed. Because of the act of efficient use of time that increase the success, relationship between the academic success and the time management of the students were examined. The main purpose of the study is to determine relationship between time management (and sub-dimensions of it) and academic success of the students. For this, a research conducted on a sample which consist of the students (275) who study at Hopa Faculty of Business Administration and Economics in Artvin Coruh University. At the end of this study, also it was low level, time management and sub-
\end{abstract}


dimensions of it relate to the academic success, and also the finding that time management and sub-dimensions of it effect the academic success were reached.

Key Words: Time, Time management, Academic success

JEL Classification: M10, M19

\section{GİRIŞ}

Kaynakların etkin kullanımının giderek daha hayati bir zorunluluk haline geldiği bir dönemi yaşıyoruz. Bu kaynaklar çeşitli olmasına rağmen, zaman, geri dönüşü olmaması sebebiyle diğerlerinden ayrılmaktadır. Özellikle her kaynak gibi zamanın da etkin yönetilmesi gerektiği gerçeği bireyleri ve örgütleri bugün giderek daha fazla zorlamaktadır. Geleneksel bir söylem olarak paranın zaman değeri söylemi, zamanın parasal değeri gibi bir söyleme dönüşerek, işletmeleri ve bireyleri, zamanı yönetemedikleri sürece oldukça büyük maliyetlere katlanmak zorunda bırakmaktadır (Oshagbemi, 1995, s.31).

Özellikle son yıllarda örgütsel literatürde zamanın önemi konusuna artan bir ilginin gösterildiğine şahitlik ediyoruz. Bu bağlamda zaman yönetimi adı altında yapılan çalışmalar bu konuya olan ilginin somut birer göstergesidir. Araştırmacıların bir kısmı teorik modelleri içerisinde zaman konusunu irdelerlerken, bir kısmı da örgütlerdeki bireylerin zamanlarını nasıl yönettiklerini ve bu zamanı yönetme çabalarının nasıl geliştirileceği konusunu irdelemektedirler (Claessens, Erde, Rutte \& Roe, 2007, s. 256).

\section{ZAMAN KAVRAMI}

Zaman, anlaşılması açısından kolay bir kavram değildir. İnsanlar zaman kavramını birçok farklı yolla tanımlamaya çalışmışlardır. Zamanın devamlılık hızının ölçümü ve saatler yoluyla rakamsal sıralanışını görmemiz mümkündür, fakat bütün bunlar zamanı gerçekten anlamamızı sağlamaktan çok öte ifadelerdir. Zamanı anlama konusunda farklı bakış açıları mevcuttur. Newton açısından zaman, fizik bakış açısıyla, diğer fiziksel fenomenlerden ve mutlaklardan bağımsızdır. Öte yandan zamanın uzayın dördüncü bir boyutu olduğu ve zamandaki değişikliklerin geri döndürülemez olduğu sonucunu içeren teorilerde de yer almıştır. Örneğin Sorli "fiziksel zamanın sadece bir değişim akımı olarak var olduğunu" ifade etmektedir. Bu tanımlamaların dışında zamanı anlaşılması daha kolay kavramlarla ilişkilendirerek anlatan 
tanımlamalarda mevcuttur. Boroditsky, zamanın, zaman-mekansal bir mecazlar grubu olarak anlaşılabileceğini ve bunun uzay ve zaman arasındaki ilişkilere yol açtığını ileri sürmüştür. Bununla birlikte, zamanla ilgili düşünürken, bu mecazların zorunlu olduğuna dair hiçbir kanıt bulunmadığını da belirtmektedir (Reunanen, 2015, s. 710).

Çeşitli tanımlamalara ve mecazlara rağmen, zamanı yönetmek isteyen insanlar için anlamlı olan şey, zamanın depolanamayan, zamanın bozulabilen, yerine konulamayan ve ikame edilemeyen benzersiz bir kaynak olmasidır. Talep, zamanı etkilemez ve fiyatı veya marjinal fayda eğrisi yoktur. Modern çalışma yaşamında zamanla ilgili konuşurken, her zaman arzı kısa, yani her zaman yokluğunu çektiğimiz bir kavramdır. İnsanın ömrünün zaman ile sınırlı oluşu da bu zamanın etkin bir biçimde kullanılmasını gerekli kılmaktadır (Mackenzie,1987, s.14, Reunanen, 2015, s. 710).

Zaman Türk Dil Kurumu (TDK) sözlüğünde aşağıdaki karşılıkları ile yer almaktadır. 1. Bir işin, bir oluşun içinde geçtiği, geçeceği veya geçmekte olduğu süre, vakit 2. Bu sürenin belirli bir parçası; 3. Belirlenmiş olan an; 4. Çağ, mevsim; 5. Bir ise ayrılmış veya bir is için alışılmış saatler, vakit; 6 . Dönem. devir (http://www.tdk.gov.tr)

\section{ZAMAN TÜRLERI}

Zaman kavramının herkes için aynı olup olmadığı noktasından hareketle objektif ve subjektif zaman şeklinde ikili bir sinıflamaya gidilmektedir. Objektif zaman, zamanın değişim hızının herkes için aynı olduğu zaman türüdür ve kronolojik zaman olarak da adlandırılır. Subjektif zaman ise yüksek bir görecelilik ifade etmektedir. Bu zaman türünde zamanın hızı, bireyin zaman deneyimini etkileyen çeşitli farklı faktörlere bağlıdır. Bunlar; zamandan yararlanma, zamanın sıralı bir takım işleri yapmak için harcanması gerekliliği, bireyin o an hissettiği duygular, bireyin kültürel geçmişi, içinde bulunulan koşullar, zaman baskısı seviyesi, uykusuzluk, kişisel bir takım özellikler gibi faktörlerdir (Reunanen, 2016, s. 112).

Objektif ve subjektif zaman ayrımının kökleri Antik Yunan'a kadar uzanmaktadır. Yunanlılar zamanı Zeusun babası olan Chronos ve Zeusun oğlu olan Kairos ile 2'ye ayırmışlardır. Chronos, zamanı mekanik olarak adlandırdığımız aralıklarla ölçerken, Kairos için zaman, içinde bulunulan 
koşullar ve ruh haline göre değişen bir kavramdır. Chronos'un zamanı akıp giden (gün,saat, ay, yıl vb.) ve herkes için aynı biçimde anlaşılan bir zamandır. Oysa Kairos'un zamanı herkesin kendisine ait sahip olduğu öznellik içeren zamanı temsil etmektedir. Chronos'un zamanı niceliksel, Kairos'un zamanı nitelikseldir. Herkes Chronos'un zamanını istesin istemesin yaşar ve tüketir. Fakat anı yaşamak olarak adlandırdığımız şey herkes için farklıdır. Kairos'un zamanı, kimi zaman akan zamanın daha yavaş akmasını isteyeceğimiz, zamanın durmasını isteyeceğimiz, ya da keşke daha hızlı aksa diyeceğimiz durumları anlatmaktadır (Reunanen, 2016, s. 112).

Zaman kavramı, zihinsel ve aynı zamanda sosyal bir olgudur. İnsanın gün periyoduna bağlı biçimde, vücuduna ait etkinliklerini düzene sokan "biyolojik bir saati" olduğu gibi, yaşadığı olayları kronolojik açıdan sıralamasına olanak sağlayan bir de "zihin saati" vardır. Zihin saati insanın geçmişten bugüne kadar yaşadıklarının belirli bir sıra ile beyinde yer almasını sağlar. Her bir olay bu zihin saatinde bir yere kaydedilir. Olayların süresi, olayların ne zaman gerçekleştiği gibi hususlar olayların zihindeki yerleşimleri yardımıyla hatırlanır (Candaş, 2002,s. 52).

Zaman algis1, aynı zamanda sosyal bir olgudur. Zamanın ilerlemesi bireyler için çocukluktan yetişkinliğe geçişi ifade ederken, toplum için bireyin zamanı nasıl kullandığ 1 ve bireyin bir konumu elde etmesi ile ilgili firsatlara aracılık edip etmediği yönüyle değerleme konusu olacaktır. Bireyin toplumda yaşa bağlı olmayan bir biçimde bir konum alması için bir değerleme aracı olacaktır (Elias,2000, s. 24).

Zamana ilişkin bir diğer tanımlama ise sosyo-kültürel zaman tanımlamasıdır. Sosyo-kültürel zaman, her bir bireyin, grubun, organizasyonun ve kültürün zaman kavramını farklı biçimlerde anladığını, zamanla farklı bir biçimde bağ kurduğunu ifade etmektedir. Her kültür, büyük ölçüde, üyelerinin zamana bağlı olma biçimiyle karakterize edilmektedir. Her kültür, geçmiş, bugün ve geleceğe yüksek derecede önem atfedebilir ve üyelerinin eylemlerini bu zamanlardan birine veya bir kaçına odaklayabilir. $\mathrm{Bu}$ tür bir odağın, onların yaşamlarındaki her önemli karar alma noktasında kararlarına etki etmesi kaçınılmazdır. Örneğin, farklı kültürler geleceğe yönelik farklı tutumlar geliştirirler. "Kader her şeyi belirler" gibi bir söylem buna örnek verilebilir. Belirli bir kültürde zamana dair genel algilardan 
bağımsız olarak, birey aynı zamanda kendine özgü kişisel deneyimlerinden yola çıkarak, zamanla olan ilişkisine dair kendi kimliğini geliştirir (Passig, 2005, s. 28).

\section{ZAMAN YÖNETIMI}

Zaman yönetimi kavramı, zamanı yoğun biçimde çalışmakla geçen yöneticilerin zamanlarını daha iyi organize etmelerine yardımcı olmak üzere bir eğitim aracı olarak ilk kez Danimarka'da doğmuş ve dünyaya yayılmıştır (Güçlü, 2001, s. 88).

Zaman yönetimi ifadesi, zamanın insanın isteği ve denetimi dışında akıp gitmesi, insanın zamanın akmasına müdahale edememesinden dolayı yönetilemeyeceği düşüncesiyle eleştirilmektedir. Aslında yaşanan durumun, bireyin sadece kendisini zamana göre yönettiği gerçeği olduğu ifade edilmektedir (Josephs, 1996, s. 8).

Lakein'in (1973) zaman yönetimini; "ihtiyaçları belirlemek, bu ihtiyaçlara ulaşmak üzere amaçlar belirlemek, bu amaçlara ulaşmak için gerekli görevleri planlamak ve bunlara öncelik tanımak" şseklinde tanımladığını görmekteyiz (Francis-Smythe ve Robertson, 1999, s. 334).

Zaman, tüm bireyler üzerinde baskı yaratan evrensel bir kaynaktır ve zamanın yönetimi bireylerin zihninde yer alan planların belirli bir takvim içerisinde gerçekleştirilebilmesidir (Cüceloğlu, 1999, s. 287).

Covey ve arkadaşları (1994), zaman yönetimi kavramının 4 temel dönemi içerdiğini ifade etmektedir. İlk dönem zaman yönetimi kavramının "hatırlatıcılar" ile ilişkili olduğunu, küçük notlar ve kontrol listeleri ile karakterize edilebileceğini ifade etmektedir. İkinci dönem zaman yönetimi kavramı ise; daha fazla planlama yapma, hazırlanma, amaç belirleme ve takvim oluşturma, zamana ilişkin takvimleri ön plana çıkarma ve randevuları kâğıtlara ya da bilgisayarlara not alma gibi uygulamalarla ifade edilmektedir. Üçüncü dönem bu uygulamalara; öncelik verme ve değerlerin gözden geçirilmesi yönüyle bir kontrolün yapılması, uzun dönemden kısa döneme doğru amaçların sıralanması, günlük öncelik verilecek konuların belirlenmesi gibi gerek kâğıda gerekse bilgisayara bu konuların not alınmasını içeren uygulamalar ilave olmuştur. Bu üç dönemin insanların etkinliğini arttırmasına rağmen, Covey ve arkadaşları (1994) bu üç döneme ilişkin yaklaşımları bazı 
yönleriyle eleştirmektedirler. Covey ve arkadaşlarına (1994) göre bu üç dönem, etkinlik ve organizasyona vurgu yapma yoluyla, insanların kendileri için neyin önemli olduğunu fark etmelerini engellemiş ve bu önemli gördükleri konularla, bu konularda zamanlarını nasıl harcayabileceklerini eşleştirmelerine imkân tanımamıştır. Covey ve arkadaşları (1994) ilk üç dönemin en iyi özelliklerini alan, ancak, yaşamda gerçekten önemli olan nedir? sorusu üzerine odaklanıp bunun üzerine daha fazla zaman harcamak üzerinde yoğunlaşmayı savunan dördüncü bir dönemi savunmaktadırlar. Bu yönüyle dördüncü dönem bireyin kendi kontrolünde olan bir eylem ve eyleme harcanacak zamanı seçme özgürlügünü veren bir dönemdir (Green ve Skinner, 2005, s. 126).

Kelly zamanın etkin kullanımını; "bireyin zamanını en iyi kullanım biçimi" şeklinde ifade etmektedir. Bu tanımlama özü itibariyle; "bir sonucu en düşük zaman kaybı ile üretmeyi" ifade etmektedir. Bu tanımlama çıktı/zaman şeklinde ifade edilebilir. Fakat zamanın etkin kullanımı her zaman hız demek değildir. Bir sonuca en düşük zaman kaybı ile ulaşılması yani diğer insanlara göre hızlı olmak her zaman bir mukayese için ilk ve tek koşul değildir. Çıktının niteliklerinin önem kazanması durumunda, çıktının hızlı bir biçimde gelişigüzel elde edildiği kanaati hızın olumsuz bir biçimde değerlendirilmesine neden olacaktır (Kelly, 2002,s. 13).

Kelly zamanın etkin kullanımı ile ilgili 3 hususa dikkat çekmektedir. $\mathrm{Bu}$ hususları; zamanla ilgili bir farkındalığa sahip olmak, zamanı dolduran eylemlerin farkında olmak ve olumlu iş alışkanlıkları şeklinde ifade etmektedir. Bu hususlar aşağıdaki gibi özetlenebilir (Kelly, 2002, s. 13).

Zamanla ilgili bir farkındalığa sahip olmak zamanın kavramsallaştırılması ile işlerlik kazanmaktadır. Zaman, bir organizmanın kendisini adapte olacak biçimde organize etmesine izin veren, böylece organizmanın davranışlarını çevresi için ardışık ilişkilere dönüştürmesini sağlayan, bilinçli ve deneysel bir ürün elde etmesi sürecidir. Zaman bu yönüyle bireyin deneyimleriyle algıladığı bilişsel bir yapıyı temsil etmektedir. Organizmanın, belirli bir dereceye kadar düzen içinde gerçekleştireceği davranışlarını ve olayları organize edeceği bir yapıyı sağlar. Zamanın anlaşılması ve kullanımı (dün, bugün, yarın) düşünsel süreçlere ilişkin bir bilinç gerektirir. 
Zamanı dolduran eylemlerin farkında olmak, en az 3 bölümden oluşur. Bunlar, zamanın doldurulacağı eylemleri anlamak, bu faaliyetlere ilgi duymak, dikkat göstermek ve zamanı dolduran aktivitelere ya da görevlere ilişkin bir yaklaşımın planlanması şeklinde ifade edilebilir.

Olumlu iş allşkanlıklarl, bir görevin veya faaliyetin tamamlanması sırasında kişilerin kullandığı yaklaşımları (bilişsel ve davranışsal) içerir. Pozitif çalışma alışkanlıkları en az üç öğe içerir; motivasyon, öz disiplin ve zaman yönetimi davranışları.

Zaman, gerek insanın yönetmek için bireysel sorumluluğa sahip olması gereken, gerekse insanlara iş imkânı sağlayan işletmelerin yönetim kademeleri açısından takip edilmesi ve değerlenmesi gerekli bir husustur. Zaman konusu, içerdiği birçok faktör açısından yönetimin ilgi alanına girmektedir. İlk olarak, yönetim kademesinde yer alan ve politikaları uygulamak zorunluluğuna sahip yöneticilerin çok azı kıt bir kaynak olan zaman konusuna kafa yormaktadırlar (iş yoğunluğu, işleri yetiştirme arzuları vb. sebeplerle). İkinci olarak, gerek bireyler gerekse yönetim büyük olarak adlandırabileceğimiz zaman harcattırıcılar konusunda çok az kafa yormaktadırlar. Bu zaman harcattırıcıların bir kısmı içsel bir kısmı dışsal olabilmektedir. Üçüncü olarak, yönetim uygulamalarının değerlendirilmesi aslında farklı türdeki birçok aktivite için harcanan zamanın eşsiz bir kombinasyonunu ifade etmektedir. Değerlendirme analizi ile değerlenen bir anlamda zamandır. Dördüncü olarak, zamanın etkinliğini ve işlerin yapılmasında etkili kullanımını göstermesi açısından önemlidir. Beşinci olarak yönetimin etkililiği konusunda, zaman, karşılaştırma yapmaya ilişkin ölçülebilir tek husustur. Altıncı olarak; yönetimin değerlemesinde kullanılmak üzere zaman, herhangi bir kişinin ne istediği ve onu elde etmek arzusuyla, diğerlerinden farklı olarak, nelerden vazgeçtiği arasındaki ilişkiyi kurmamızı sağlar. Ayrıca zamanın yönetimi etkin bir biçimde kullanılmalıdır çünkü zaman kaybı ebedi bir kayıptır ve geri getirilemez (Deb, 2001:2)

\section{ZAMAN YÖNETIMİ YAKLAȘIMLARI}

Zaman yönetimi konusunda birçok yaklaşım ifade edilmekle birlikte en fazla karşılaşılan bir kaç yaklaşım biçimi aşağıdaki gibi verilebilir.

\section{Düzenli Yaşam Yaklaşımı}


Hayatın birçok alanında sorunlar düzen eksikliğinden ortaya çıkmaktadır. Nesneler ve insanlar arasındaki ilişkiler, insanların diğer insanlarla ilişkileri gibi birçok husus belirli bir düzen korunarak sürdürüldüğünde bu konulara ayrılan zaman doğrudan azalacaktır (Sabuncuoğlu ve Paşa, 2002, s. 28).

\section{Savaş̧ıı Yaklaşım}

Birçok işi yapmak zorunda olduğumuz yaşamımızda, kendimize ayırdığımız zamanı azaltmaktan vazgeçmeksizin, işleri daha verimli yapmanın yolarını bulmamızı ifade etmektedir. Bu yaklaşım etkin bir planlama, önemli ve önemsiz işlerin ayıklanması gibi birçok yaklaşımla desteklenmelidir (Sabuncuoğlu ve Paşa, 2002, s. 30).

\section{Hedef Belirleme Yaklaşımı}

Doğru bir amaçlar dizisinin belirlenmesi ve o amaç için azami gayretin gösterilmesi ile ifade edilebilir. Ulaşılacak hedeflerin kısa, orta ve uzun vadeli biçiminde düzenlenmesi eylemlerin sıralı olması ve ardışıklığı konusunda bireye rehberlik sağlayacaktır (Sabuncuoğlu ve Paşa, 2002, ss. 34-35).

\section{Sihirli Araç Yaklaşımı}

Doğru amaç kadar doğru aracın kullanılması da önem arz etmektedir. Amaçların doğru belirlendiği ve arzu edilirliğinin yüksek olduğu bir durum bu amaç için en doğru aracın kullanılmasını da gerekli kılacaktır (Sabuncuoğlu ve Paşa, 2002,s. 38).

\section{Kendini Akıntıya Bırak Yaklaşımı}

$\mathrm{Bu}$ yaklaşım insanın kendisini zamanın doğal akışı içerisine bırakmasını ifade etmektedir. $\mathrm{Bu}$ yönüyle zamanın yönetilmemesini bir yönetim biçimi olarak karşımıza getirmektedir. İnsan yaşamının, kıt kaynaklar ile sınırsız olan ihtiyaçlarını tatmin etmek için teste tabi tutulduğu hayat döngüsünde, zaman gibi kıt bir kaynağın ihtiyaçların tatmini noktasında için en verimli kaynak olarak ele alınması elzemdir (Tutar, 2003,s. 54).

Zamanın yönetimi bir süreç olarak aşağıdaki gibi örneklendirilebilir (Gümüş, 1999, ss. 391- 392).

\section{1. Öncelikle bir zaman kütü̆̆̈̈ hazırlanır}

Güne dair zamanın nasıl harcandığını analiz etmek için gereklidir. Zaman kendi içinde uygun görülen dilimlere bölünür. Yapılan işler kaydedilir. $\mathrm{Bu}$ işlere ayrılan zamanlar not edilir. Önem derecesine göre farklı işlere 
ayrılan zamanlar bir kıyaslamaya tabi tutulur. Belirli bir süre bu denemeler sürdürülür ve gün sonlarında rutin kontroller yapılır. Edinilen bu tecrübe zaman planı yapma konusunda oldukça önemlidir.

\section{Daha sonra günlük zamanın nasıl kullanılacağını gösteren bir plan hazırlanır}

Yazılı bir plan olması gerekmemekle birlikte bir sonraki güne planlı başlamak önemlidir. $\mathrm{Bu}$ plan dâhilinde, günlük ve haftalık işlerin belirlenmesi, işlerin neden yapılması gerektiği, muhtemel faydaları, yapılmaması durumunda neler olabileceği gibi fayda ve maliyeti içeren bir analiz yapılmalıdır.

\section{Hazırlanan plan uygulanir}

İşlerin önem derecesine göre gün içinde en enerjik olunan zamanlar daha önemli işlere ayrılmalı, kolay işler zor işler arasına gelecek biçimde yapılmalı, önemsiz işler çalışma veriminin düştüğü saatlere konulmalı, önem derecesi düşük işler için karar verme zamanı kısaltılmalıdır.

4. Günün bitiminde, zamanın nasıl harcandı̆̆ı mutlaka kontrol edilmeli, günün değerlendirmesi yapılmalıdır.

Günün sonunda işlerin ne ölçüde başarıldı̆̆ 1 , belirlenen zamana ne ölçüde uyulduğu, sapmaların nelerden kaynaklandığı konusu belirlenmeli, planlama yaparken ve standartlar belirlerken bu unsurlar göz önünde bulundurulmalıdır.

Akgemci ve diğerleri (2003) ise zaman yönetimini sekiz aşamadan oluşan bir süreç olarak ifade etmektedirler (Akgemci, Çelik, Aydoğan ve Akatay, 2003,s. 41).

- Zaman kullanım analizi (zaman cetveli)

- Zaman problemlerini tanımlama

- Kendini tanımlama

- Amaç ve öncelikleri belirleme

- Program hedeflerini uygulama planına aktarma

- Günlük programlar ve rehberler hazırlama

- Zaman yönetimi tekniklerini geliştirme

- Sürecin izlenmesi ve yeniden analiz 


\section{ZAMAN HARCATTIRICILAR (TUZAKLARI)}

Zaman yönetiminin işleyişine etki eden unsurlar literatürde zaman harcattırıcılar (tuzakları) olarak adlandırılmaktadır. Bu tuzakların bir kısmı bireyden kaynaklanırken (içsel) bir kısmı bireyin çevresinden (dışsal) kaynaklanmaktadır. Bu tuzakları aşağıdaki gibi ifade etmek mümkündür (Deb, 2001,s.7, Brittain ve Hull,2003,s. 367).

- Telefon ve iletişim araçlarının kullanımı,

- Habersiz ziyaretçiler,

- Programlanmış ve programlanmamış görüşmeler,

- Planların var olmadığı kriz zamanları,

- Amaçların, önceliklerin ve bunların bitiş tarihlerinin belirli olmamas1,

- Dağınık masa düzeni ve düzensizlik,

- Devredilmesi gereken işleri devretmemek,

- Hızlıca bir işe girişip işin ne kadar zaman alabileceğini kestirememiş olmak

- Açık bir sorumluluk ve otorite hattının belirlenmemiş olması,

- Yetersiz, yanlış ya da ertelenmiş bilgi akışı,

- Kararsizlık ve erteleme,

- İletişim eksikliği,

- Hayır diyememek,

- Yorgunluk

\section{ZAMAN YÖNETIMII İLE İLGILI ÇALIŞMALAR}

Zaman yönetimi gerek öncüllerinin gerekse sonuçlarının araştırıldığı birçok çalışmaya konu olmuştur. Zaman yönetiminin öncülü olarak araştırılan değişkenler temelde 2 başlık altında toplanabilir. Bunlar; bireylerin kişilik özellikleri ve zaman yönetimi eğitim programlarıdır. Bu bağlamda zaman yönetiminin öncülü olarak kişilik özelliklerinin araştırıldığı çalışmalara ilişkin bazı örnekler aşağıdaki gibi verilebilir.

Bond ve Feather (1988) "big five" kişilik özellikleri ile zaman yönetimi arasındaki ilişkiyi incelemişlerdir. (Bond ve Feather, 1988,s. 323) 
Lay ve Schouwenburg (1993) ertelemecilik kişilik özelliği ile yani başka bir deyişle işe başlama ve bitirme konusunda geçiştirme eğilimi davranışı ile zaman yönetimi arasındaki ilişkiyi incelemiştir (Lay ve Schouwenburg,1993, s.647).

Shahani ve diğerleri (1993) zaman yönetimi davranışları ile kırılganlığı stres seviyesine indirgemeye yardımcı olacaklarını düşündükleri, uyum duygusu arasındaki ilişkiyi incelemişlerdir (Shahani, Weiner \& Streit, 1993, s.231).

Kaufman-Scarborough ve Lindquist (1999) ise zaman yönetimi ile zamana karşı çoklu görevlerin yerine getirilmesi konusunda bireyin sahip oldukları 2 tarz (aynı anda 2ya da daha fazla işi yapmayı tercih eden ve ardışık biçimde gelen görevleri tercih edenler) arasındaki ilişkiyi incelemişlerdir (Kaufman- Scarborough ve Lindquist, 1999, s. 288).

Zaman yönetiminin öncülü olarak, zaman yönetimi eğitim programlarının ele alındığı çalışmalar incelendiğinde, bunun Lakein'in zaman yönetimi tanımına kadar uzandığı görülmektedir. Lakein (1973) bireylerin önce ihtiyaçlarını ve isteklerini belirlediğini; önem derecesine göre bunları sıraladıklarını; bu ihtiyaçları ve istekleri başarmak için amaçlar içeren aktiviteler belirleyerek, en üst düzeye sahip görevleri, planlama, bir takvim belirleme, listeler yapma yoluyla uygun zaman ve kaynaklarla eşleştirdiğini ifade etmektedir. Macan (1990) Lakein'in bu tanımlamasıyla uygun 3 zaman yönetimi faktörü ortaya koymuştur. Bunlar a) amaçlar ve önceliklerin belirlenmesi, b) zaman yönetimi teknikleri (listeler hazırlamak) ve c) örgüt için öncelikli bir tercih olması (Macan, 1994, s. 381)

Zaman yönetimi eyleminin sonuçları açısından incelendiği araştırmalara bakıldığında bu araştırmaların bir kaç grup altında toplandığını görmekteyiz. Bunların ilki zaman yönetiminin nispeten yakın vadeli sonuçları olarak; zaman süresinin doğru tahmin edilip edilmediği, yüksek önceliğe sahip görevlere zaman harcama konusu, sonuçları elde etme oranını arttırmak için planların yeniden düzenlenmesi ile ilgili beceriler gibi konular incelenmiştir. İkinci grup çalışmalar -bu araştırmanın da konusunu oluşturmaktadır- zaman yönetiminin iş performansı ve akademik sonuçlar (akademik performans) üzerindeki etkisini araştırmaktadır. Üçüncü grup 
çalışmalar ise zaman yönetiminin bireyler üzerindeki tutumla ve stresle ilgili etkileri ile ilgilidir.

Zaman yönetiminin bireyler için neden bir problem konusu olduğu ile ilgili özellikle ekonomistler ve psikologlar konuya bir açıklık getirmeye çalışmışlardır. Yönetilecek zaman, içerisinde birçok işi ve kararı barındırmaktadır. Bu işlerin ne olduğunu belirleme ve karar verme özgürlüğü azaldıkça zaman yönetimi konusu bireylerin ilgilerini yeterince çekmemektedir. Araştırmacılar bireylerin eğer bu özgürlükleri var ise bu defa en fazla faydayı elde edecekleri işleri tercih ettiklerini ifade etmektedirler. Fakat hangi işin en fazla fayda sağlayacağı işler tamamlanmadığı için henüz anlaşılmadığından birey için ortada bir bilinmezlik söz konusudur. Ayrıca işler büyüklükleri ve önemleri açısından mukayese edildiği gibi elde edilecek faydanın vadesine göre de bireyler tarafindan bir değerlendirmeye tabi tutulurlar. Özellikle bu değerlendirmeye ilişkin en güzel örnek ekonomi alanında karşımıza çıkmaktadır. Bireyler vadenin uzayıp karın (faydanın) artacağı bir ekonomik sonuç yerine, vadenin kısalıp karın (faydanın) azalacağı bir sonucu tercih etmektedirler.(Konig ve Kleinmann, 2007, s. 322)

Bir başka deyişle, bireyler acil ama önemsiz görevleri, önemli ve acil olmayan görevlere tercih etmektedirler. Zamanın kısalmasından dolayı, kısa vadede elde edilecek faydalar ve katlanılacak maliyetler, gelecekte elde edilecek faydalar ve katlanılacak maliyetlere göre daha ağır basacaktır (Konig ve Kleinmann, 2007, s. 323)

\section{ZAMAN YÖNETIMI VE AKADEMIK BAŞARI ARASINDAKİ ILISSKKIYYI İNCELEYEN ARAŞTIRMALAR}

Zaman yönetimleri ile akademik başarı arasındaki ilişkiyi inceleyen çeşitli araştırmalar mevcuttur. $\mathrm{Bu}$ araştırmaların bazılarını aşağıdaki gibi vermek mümkündür.

Alay ve Koçak (2003) ODTÜ'de eğitim gören üniversite öğrencilerinin zaman yönetimleri ile akademik başarılarını inceledikleri çalışmalarında, öğrencilerin Genel Akademik Not Ortalamaları (GANO) ile "Genel Zaman Yönetimi" arasında pozitif yönlü, Genel Zaman Yönetiminin alt boyutlarından "zaman planlaması" ile pozitif yönlü ve diğer alt boyutlardan "zaman harcattırıcılar" arasında negatif yönlü anlamlı bir ilişkinin olduğu 
bulgusuna ulaşmışlardır. Ancak GANO ile bir diğer zaman yönetimi alt boyutu olan "zaman tutumu" arasında anlamlı bir ilişki bulamamışlardır.

Ayrıca öğrencilerin, genel zaman yönetiminde ve zaman planlaması alt boyutunda cinsiyete göre anlamlı bir farklılığa sahip oldukları, kız öğrencilerin erkek öğrencilerden daha başarılı oldukları bulgusuna ulaşmışlardır (Alay ve Koçak, 2003, s.326).

Durmaz, Hüseyinli ve Güçlü (2016) Alanya Alaattin Keykubat Üniversitesi, Turizm İşletmeciliği bölümü ve Alanya'da çeşitli liselerde eğitim gören öğrencileri kapsayan bir örneklem üzerinde yapmış oldukları çalışmada, zaman yönetimini; planlama, önceliklendirme, programlama, erteleme, tuzaklar, önem verme, inanma şeklinde 7 boyut altında ele almışlar ve her bir zaman boyutunun, akademik başarı düzeyine göre farklılık gösterip göstermediğini araştırmışlardır. Çalışma sonunda, not ortalaması yüksek öğrencilerin zaman yönetiminin; planlama, önceliklendirme, tuzaklar ve yoğunlaşma boyutuna ilişkin algılamalarının da yüksek olduğu bulgusuna ulaşmışlardır. Öğrenciler, not ortalamaları açısından diğer zaman boyutlarında anlamlı bir farklılık göstermemektedirler. Ayrıca öğrencilerin, cinsiyete göre, sadece erteleme boyutunda bir farklılığa sahip oldukları görülmüştür. Kızların erteleme konusundaki ortalamaları erkeklerden daha yüksektir (Durmaz, Hüseyinli ve Güçlü, 2016, ss. 2297-2298)

Tanriöğen ve İşcan (2009) öğrencilerin zaman yönetimi becerilerinin akademik başarılarını etkileme gücü konusunda yaptıkları çalışmada, öğrencilerin akademik başarıları üzerinde zaman planlamasının \%4.7, zaman yönetimi tutum ve becerilerinin \%3.8, zaman harcattırıcıları ile başa çıkma becerilerinin ise \% 4.3 oranında bir etkileme gücüne sahip olduğu bulgusuna ulaşmışlardır. (Tanrı̈̆ğen ve İşcan, 2009, s. 95)

Yavaş, Öztürk, Açıkel ve Özer (2002) tıp fakültesi öğrencileri ile yürüttükleri bir araştırmada, akademik başarının tam bir karşılığı olmasa bile, başarısızlık açısından bir gösterge olan sene kaybı veya staj kaybı ile zaman yönetiminin alt boyutu olan, zaman harcattırıcılar arasında, öğrencilerin ortalamaları açısından anlamlı bir farklılık olduğu bulgusuna ulaşmışlardır. Başarısız olan öğrencilerin zaman harcattırıcılar ölçeğinde daha yüksek bir ortalamaya sahip oldukları görülmüştür. Bunun ise, üst üste sınıfta kalmanın okuldan ayrilma nedeni olmasindan ve daha fazla staj ve sene kaybetmek 
istememelerinden kaynaklandığı değerlendirilmektedir. Ayrıca başarısız öğrencilerin zaman planlaması açısından daha yüksek bir ortalamaya sahip oldukları görülmektedir (Yavaş, Öztürk, Açıkel ve Özer, 2002, s. 9) Ayrıca örneklem, cinsiyet, uyruk ve sene kaybı değişkenlerine göre zaman yönetimi ortalamaları açısından anlamlı bir farklılık göstermemektedir (Yavaş, Öztürk, Açıkel ve Özer, 2002, s. 7)

Yılmaz, Yoncalık ve Bektaş (2010) spor yöneticiliği programında öğrenim gören öğrencilerle yürüttükleri bir çalışmada, öğrencilerin zaman yönetimleri değişkeni ile akademik başarıları arasında bir ilişkinin olup olmadığını araştırmışlardır. Çalışma sonunda öğrencilerin akademik başarıları ile gerek, zaman yönetimleri gerekse, zaman yönetiminin alt boyutları olan zaman planlamaları, zaman tutumları ve zaman harcattırıcilar arasında anlamlı bir ilişkinin olmadığı bulgusuna ulaşılmışlardır (Yılmaz, Yoncalık ve Bektaş, 2010, s. 191).

\section{YÖNTEM}

\section{1.Örnekleme Süreci}

Araştırmanın ana kütlesini Artvin Çoruh Üniversitesi, Hopa İ̈BF'de eğitim gören İktisat, İşletme, Siyaset Bilimi ve Kamu Yönetimi bölümü, 2. 3. ve 4. sınıf öğrencileri oluşturmaktadır. Gerek, henüz başarı notları oluşmadığından, gerekse 2017-2018 eğitim-öğretim döneminde Artvin Çoruh Üniversitesi Hopa İIBBF bölümlerine yeni kayıtlanan öğrenci sayısının düşük olması sebebiyle 1. sınıflar bu çalışmada kapsam dışı bırakılmışlardır. Fakültede öğrenim gören öğrenci sayısı (1. sınıflar hariç) 480'dir. Örneklem Basit Olasılıklı (Rastgele) Örnekleme Yöntemi ile belirlenmiştir. Bu çalışma kapsamında 334 öğrenciye ulaşılmıştır. Bu öğrencilerin 275 'inden elde edilen veriler değerlemeye uygun görülmüş; 59 değerleme formu ise, bazı ifadelerin işaretlenmeyerek boş bırakılması ve tutarsız biçimde doldurulması nedeniyle değerleme dişı bırakılmıştır.

\subsection{Veri Toplama Yöntemi ve Aracı}

Çalışmada veriler anket yöntemi ile elde edilmiştir. Anketlerin tümü yüz yüze görüşülerek doldurtulmuştur. Anket formunda toplam 32 ifade yer almaktadır. İfadelerin 4'ü demografik özellikler, 1'i ağırlıklı genel not 
ortalamas1, 27'si ise zaman yönetimi ile ilgilidir. Ankette yer alan zaman yönetimi ile ilgili ifadelerin değerlendirilmesinde 5'li Likert ölçeği (1:Hiç, 5: Her zaman) kullanılmıştır. İfadelerden 8 tanesi ters ifade olarak sorulmuş ve veri girişi sırasında puanlama ters çevrilerek girilmiştir.

Zaman yönetimine ilișkin ifadeler, orijinali Britton ve Tessers (1991) tarafindan hazırlanan ancak sonrasında Alay ve Koçak (2002) tarafindan uyarlanan 27 ifadeli ölçekten (16 ifade zaman planlaması, 7 ifade zaman tutumu, 4 ifade zaman harcattırıcılar) alınmıştır. Alay ve Koçak'ın (2002) çalışmasında Cronbach $\alpha$ değerleri ölçeğin tümü için 0,87 , alt boyutları için ise 0,47 ile 0,88 arasında bulunmuştur. Elde edilen verilerin test edilmesinde SPSS 20 paket programından yararlanılmıştır.

\subsection{Verilerin Analizi}

Verilen analizleri için yapılan işlemleri 5 başlık altında toplamak mümkündür. Sırasıyla ilk olarak verilerin analizi için öncelikle örneklem grubuna ilişkin demografik özellikler ifade edilmektedir. İkinci olarak öğrencilerin bölümleri, sınıfları ve cinsiyetlerine göre AGNO'ları açısından bir farklılık olup olmadığını görmek üzere bağımsız $t$ testi ve Anova analizleri yapılmıştır. Üçüncü olarak zaman yönetimi ölçeğine faktör analizi yapılmıştır. Dördüncü olarak, demografik özelliklere göre zaman yönetimi ortalamaları belirtilmiştir. Beşinci olarak, zaman yönetimi ile AGNO arasında bir ilişkinin var olup olmadığını görmek için korelasyon analizleri yapılmıştır. Son olarak zaman yönetiminin AGNO üzerinde bir etkisinin var olup olmadığını görmek üzere regresyon analizleri yapılmıştır.

\section{BULGULAR}

\subsection{Cevaplayıcıların Demografik Özellikleri}

Araştırma kapsamında ele alınan örneklem'e ilişkin demografik veriler (frekans ve yüzdeleriyle birlikte) ve demografik bazda Ağırlıklı Genel Not Ortalamaları (AGNO), Tablo 1'deki gibi verilmektedir. Bu sonuçlara göre SBKY bölümü en yüksek AGNO değerine sahiptir, 4. sınıflar en yüksek AGNO değerine sahiptir, Kadın öğrencilerin AGNO'su erkek öğrencilere göre anlamlı bir oranda yüksektir. Tüm örneklem için AGNO değeri 2,4472 olarak bulunmuştur. 
Tablo 1. Örnekleme ilişkin demografik veriler ve AGNO ortalamaları

\begin{tabular}{|c|c|c|c|c|c|}
\hline \multicolumn{2}{|c|}{ Demografik Özellikler } & \multirow{2}{*}{$\begin{array}{l}\text { Frekans } \\
\text { (F) } \\
90\end{array}$} & \multirow{2}{*}{$\begin{array}{l}\begin{array}{l}\text { Yüzde } \\
(\%)\end{array} \\
32,7\end{array}$} & \multirow{2}{*}{$\begin{array}{c}\text { AGNO } \\
2,3128\end{array}$} & \multirow[t]{2}{*}{$\begin{array}{l}\text { Tüm Örneklemin } \\
\text { AGNO Ort. }\end{array}$} \\
\hline \multirow{3}{*}{ Bölüm } & İktisat & & & & \\
\hline & İşletme & 96 & 34,9 & 2,5111 & \multirow{11}{*}{2,4472} \\
\hline & SBKY & 89 & 32,4 & 2,5140 & \\
\hline \multirow{3}{*}{ Sinif } & 2.sinif & 98 & 35,6 & 2,2404 & \\
\hline & 3.sinif & 87 & 31,6 & 2,3875 & \\
\hline & 4.sinif & 90 & 32,7 & 2,7300 & \\
\hline \multirow{2}{*}{ Cinsiyet } & Kadın & 166 & 60,4 & 2,6183 & \\
\hline & Erkek & 109 & 39,6 & 2,1866 & \\
\hline \multirow{3}{*}{ Yaş } & 20 yaş ve altı & 92 & 33,5 & & \\
\hline & 21-23 yaş & 44 & 48,8 & & \\
\hline & 24 ve üstü & 21 & 7,7 & & \\
\hline \multicolumn{2}{|l|}{ Toplam } & 275 & 100,0 & & \\
\hline
\end{tabular}

\subsection{Demografik Özellikler ve AGNO Arasındaki İlişkinin Belirlenmesine Yönelik Bağımsız t Testi ve ANOVA Analizleri}

Çalışmada elde edilen verilere normallik testi uygulanması sonucunda verilerin normal dağılıma uygun olarak dağıldığı tespit edilmiştir. Bu tespite uygun olarak, öğrencilerin AGNO'larının demografik özellikler açısından farklılık gösterip göstermediğini anlamak için Anova analizleri ve Bağımsız t testleri yapılmıştır.

Tablo 2. Öğrencilerin bölümleri ile AGNO'ları arasındaki ilişkiye yönelik Anova testi

\section{ANOVA}

AGNO

\begin{tabular}{llllll}
\hline & $\begin{array}{c}\text { Kareler } \\
\text { Toplamı }\end{array}$ & $\begin{array}{l}\text { Serbestlik } \\
\text { Derecesi }\end{array}$ & $\begin{array}{l}\text { Kareler } \\
\text { Ortalamas1 }\end{array}$ & F & Anlamlılık \\
\hline $\begin{array}{l}\text { Gruplararası } \\
\text { (Illişkisiz gruplar) }\end{array}$ & 2,416 & 2 & 1,208 &, 514 &, 599 \\
$\begin{array}{l}\text { Gruplar içi } \\
\text { (İlişkili gruplar) }\end{array}$ & 639,457 & 272 & 2,351 & &
\end{tabular}


Bölüm ve AGNO arasındaki ilişkinin belirlenmesine yönelik olarak yapılan Anova analizinin sonuçları Tablo 2'deki gibidir. Anova analizi sonuçlarına göre, $\mathrm{F}(2,272)=0,514, \mathrm{p}=0,599$, öğrencilerin bölümlere göre (İktisat, İşletme, SBKY) AGNO değerleri açısından, \% 95 güven aralığında, anlamlı bir farklılık saptanamamıştır. Öğrencilerin bölümleri ile akademik başarı ortalamaları arasında anlamlı bir farklılık yoktur.

Öğrencilerin kayıtlı oldukları sınıflara göre AGNO'larının farklılık gösterip göstermediğini anlamak için Anova analizi yapılmıştır. Yapılan Anova analizinin sonuçları Tablo 3'deki gibidir.

Tablo 3. Öğrencilerin sınıfları ile AGNO'ları arasındaki ilişkiye yönelik Anova testi AGNO

\section{ANOVA}

\begin{tabular}{lccccr}
\hline & $\begin{array}{l}\text { Kareler } \\
\text { Toplamı }\end{array}$ & $\begin{array}{c}\text { Serbestlik } \\
\text { Derecesi }\end{array}$ & Kareler Ortalamas1 & F & Anlamlılık \\
\hline $\begin{array}{l}\text { Gruplararası } \\
\text { (Illş̧kisiz gruplar) }\end{array}$ & 11,699 & 2 & 5,849 & $2,525,082$ \\
$\begin{array}{l}\text { Gruplar içi } \\
\text { (̇lişkili gruplar) }\end{array}$ & 630,174 & 272 & 2,317 & \\
Toplam & 641,873 & 274 & & \\
\hline
\end{tabular}

Anova analizi sonuçlarına göre, $\mathrm{F}(2,272)=2,525, \mathrm{p}=0,082$, öğrencilerin, sınıflara göre (2'nci sınıf, 3'üncü sınıf, 4'üncü sınıf) AGNO değerleri açısından, \%95 güven aralığında, anlamlı bir farklılık bulunamamıştır.

Tablo 4. Öğrencilerin cinsiyetleri ile AGNO'ları arasındaki ilişkiye yönelik bağımsız t testi

\section{Bağımsız Örneklemler t-testi}

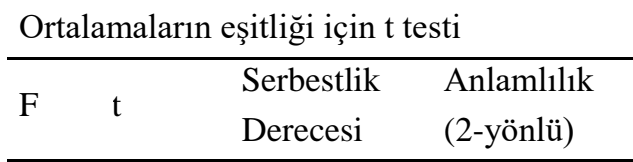




\begin{tabular}{llllll}
\cline { 3 - 5 } AGNO & $\begin{array}{l}\text { Varyansların eşit } \\
\text { olduğu varsayımı }\end{array}$ &, 517 & 2,306 & 273 &, 022 \\
& $\begin{array}{l}\text { Varyansların eşit } \\
\text { olmadı̆̆ı varsayımı }\end{array}$ & 2,748 & 206,935 &, 007 \\
\hline
\end{tabular}

Öğrencilerin cinsiyetlerine göre akademik genel not ortalamaları (AGNO) arasında bir farklılık olup olmadığını anlamak için $t$ testi yapılmıştır. Yapılan $\mathrm{t}$ testinin sonuçları Tablo 4' deki gibidir.

Cevaplayıcıların cinsiyetlerine göre akademik genel not ortalamaları (AGNO) arasında bir farklılık olup olmadığına bakıldığında, $t$ testi sonuçlarına göre $\mathrm{t}(273)=2,306, \mathrm{p}>0,022$ olarak bulunmuştur. Bu sonuçlara göre cinsiyet ile AGNO arasında, \%95 güven aralığında anlamlı bir farklılık tespit edilmiştir. Bu farklılık kadınlar lehinedir. Kadınların ağırlıklı genel not ortalamaları 2,6183 erkeklerin ağılıklı genel not ortalamaları ise 2,1866 olarak bulunmuştur.

\subsection{Zaman Yönetimi Ölçeğine İlişskin Faktör Analizi}

Zaman yönetimini ölçmek için kullanılan zaman yönetimi ölçeğine faktör analizi uygulanmıştır. Orijinal ölçekte zaman yönetimi, 3 alt faktöre sahiptir. Bunlar zaman planlaması, zaman tutumu ve zaman harcattırıcılar şeklinde ifade edilmektedir.

Yapılan doğrulayıcı faktör analizi, orijinal ölçekte var olan 3 faktörü doğrulamaktadır. Verilerin faktör analizine uygunluğu için Kaiser-MeyerOlkin (KMO) Örneklem Yeterliliği Ölçütü ve Barlett'in Küresellik Testi kullanılmıştır. Yapılan analizde $\mathrm{KMO}=0,928$ ve Barlett testi anlamlılık düzeyi $\mathrm{p}=0,000$ olarak hesaplanmıştır. Bu değerler verilerin faktör analizi uygulamaya müsait olduğunu göstermektedir. Yapılan faktör analizi sonucunda bazı ifadelerin faktör yüklerinin düşük olduğu ya da birden fazla alt faktör altında yer aldığı görülmüştür. Bu durumdaki 4 ifade $(17,19,21$ ve 25) faktör analizinden çıkartılmıştır. 4 ifadenin çıkarılmasından sonra yapılan faktör analizi sonucunda ifadelerin faktör yüklerine bakıldığında 0,609 ile 0,884 arasında değiştiği görülmektedir. Ölçeğin güvenilirliğini analiz etmek için içsel tutarlılık ölçütü olan Cronbach $\alpha$ katsayısına bakılmıştır. Zaman 
yönetimine ilişkin her bir alt faktörün Cronbach $\alpha$ katsayısına bakıldığında, $(\alpha>0.60)$ olduğu görülmektedir. Cronbach $\alpha$ değeri açısından, zaman planlamas1 0,967 , zaman tutumu 0,870 ve zaman harcattırıcılar ise 0,899 olarak bulunmuştur. $\mathrm{Bu}$ değerler oldukça yüksek olarak nitelendirilebilir. Zaman yönetimi anketi için yapılan faktör analizinin sonuçları Tablo 5'deki gibidir.

Tablo 5. Zaman yönetimi anketi için, varimax yöntemi ile döndürülmüş faktör analizi sonuçları

\begin{tabular}{|c|c|c|c|}
\hline \multirow[b]{2}{*}{ İfadeler } & \multicolumn{3}{|c|}{ Zaman Yönetiminin Alt Faktörleri } \\
\hline & $\begin{array}{l}\text { Zaman } \\
\text { Planlaması }\end{array}$ & $\begin{array}{l}\text { Zaman } \\
\text { Tutumu }\end{array}$ & $\begin{array}{l}\text { Zaman } \\
\text { Harcattırıcilar }\end{array}$ \\
\hline$\overline{\mathrm{S} 4}$ & ,783 & & \\
\hline S5 & 780 & & \\
\hline S6 & ,775 & & \\
\hline S7 &, 771 & & \\
\hline S11 & 767 & & \\
\hline S10 &, 765 & & \\
\hline $\mathrm{S} 2$ &, 763 & & \\
\hline S3 &, 762 & & \\
\hline S9 & 756 & & \\
\hline S14 & ,750 & & \\
\hline S15 &, 733 & & \\
\hline $\mathrm{S} 13$ & ,716 & & \\
\hline $\mathrm{S} 1$ &, 715 & & \\
\hline $\mathrm{S} 12$ & 698 & & \\
\hline S8 & ,655 & & \\
\hline S16r & 609 & & \\
\hline S18r & & ,884 & \\
\hline S22r & & 847 & \\
\hline S23r & & ,811 & \\
\hline S20 & &, 718 & \\
\hline S27r & & & ,824 \\
\hline S26r & & &, 773 \\
\hline $\mathrm{S} 24 \mathrm{r}$ & & & 751 \\
\hline $\begin{array}{l}\text { Cronbach } \alpha \\
\text { KMO }=0,928 \\
\text { Bartlett's Tes }\end{array}$ & $\begin{array}{r}0,967 \\
00<0,05\end{array}$ & 0,870 & 0,899 \\
\hline
\end{tabular}




\subsection{Demografik Özellikler ve Zaman Yönetimi Ölçeğine İlişkin Ortalamalar}

Zaman yönetiminin 3 alt faktörü olan, zaman planlaması, zaman tutumu ve zaman harcattırıcılara ilişkin ortalamalar demografik verilerle ilişkili olarak Tablo 6'daki gibi verilmektedir.

Cinsiyete göre; zaman planlaması, zaman tutumu ve zaman harcattırıcılar boyutlarında kadın öğrencilerin ortalamaları erkek öğrencilere göre daha yüksektir. Bu durum bu üç faktörün yönetilmesinde kadın öğrencilerin daha başarılı olduğu şeklinde ifade edilebilir. Bölümlere göre bakıldığında, zaman planlaması boyutunda İşletme bölümü öğrencilerinin, zaman tutumu açısından İktisat bölümü öğrencilerinin, zaman harcattırıcılar boyutunda ise SBKY bölümü öğrencilerinin daha başarılı olduğu söylenebilir. Sınıflara göre bakıldığında zaman planlaması konusunda 4. sınıfların, zaman tutumu açısından 2. sınıfların, zaman harcattırıcılar boyutunda ise 2 . ve 3 . sınıfların daha başarılı oldukları söylenebilir.

Tablo 6. Demografik özellikler ve zaman yönetimi ölçeğine ilişkin ortalamalar

\begin{tabular}{|c|c|c|c|c|c|c|}
\hline \multirow{2}{*}{\multicolumn{2}{|c|}{$\begin{array}{l}\text { Demografik } \\
\text { Özellikler }\end{array}$}} & \multirow{2}{*}{$\begin{array}{l}\text { Frekans } \\
\text { (F) }\end{array}$} & \multirow[b]{2}{*}{$\begin{array}{l}\text { Yüzde } \\
(\%)\end{array}$} & \multicolumn{3}{|c|}{ Zaman Yönetimi } \\
\hline & & & & $\begin{array}{l}\text { Zaman } \\
\text { Planlaması }\end{array}$ & $\begin{array}{l}\text { Zaman } \\
\text { Tutumu }\end{array}$ & $\begin{array}{l}\text { Zaman } \\
\text { Harc. }\end{array}$ \\
\hline \multirow{2}{*}{ Cinsiyet } & Kadın & 166 & 60,4 & 3,0459 & 3,0813 & 3,4116 \\
\hline & Erkek & 109 & 39,6 & 2,7419 & 3,0069 & 3,0340 \\
\hline \multirow{3}{*}{ Bölüm } & İktisat & 90 & 32,7 & 2,8625 & 3,0972 & 3,3037 \\
\hline & İşletme & 96 & 34,9 & 3,0540 & 2,9974 & 3,0972 \\
\hline & SBKY & 89 & 32,4 & 2,8516 & 3,0653 & 3,4015 \\
\hline \multirow{3}{*}{ Sinif } & 2.sinif & 98 & 35,6 & 2,7073 & 3,1480 & 3,3299 \\
\hline & 3.sinif & 87 & 31,6 & 3,0438 & 2,9828 & 3,3295 \\
\hline & 4.sinif & 90 & 32,7 & 3,0520 & 3,0140 & 3,1236 \\
\hline Toplam & & 275 & 100,0 & \multirow{2}{*}{\multicolumn{3}{|c|}{2,9919}} \\
\hline \multicolumn{3}{|c|}{$\begin{array}{l}\text { Örneklemin tümü için } \\
\text { zaman yönetimi ortalaması }\end{array}$} & & & & \\
\hline
\end{tabular}

\subsection{Zaman Yönetimi ve AGNO Arasındaki Korelasyona Yönelik Analiz}

Veriler normal dağılım gösterdiğinden zaman yönetimi ve AGNO ilişkisi için pearson korelasyon analizi yöntemi kullanılmıştır. Yapılan korelasyon analizinin sonuçları Tablo 7'deki gibidir. 
Tablo 7. Zaman yönetimi ve AGNO arasındaki korelasyona yönelik analiz

\begin{tabular}{lllll}
\hline & Pearson & $\mathbf{p}$ & Sonuç \\
\hline $\begin{array}{l}\text { Zaman planlaması ve } \\
\text { AGNO }\end{array}$ & 0,159 & 0,008 & $\begin{array}{l}\mathrm{P}<0,01 \text { olduğundan pozitif yönlü } \\
\text { anlamlı bir ilişki vardır }\end{array}$ \\
$\begin{array}{l}\text { Zaman tutumu ve } \\
\text { AGNO }\end{array}$ & 0,125 & 0,019 & $\begin{array}{l}\mathrm{P}<0,05 \text { olduğundan pozitif yönlü } \\
\text { anlamlı bir ilişki vardır }\end{array}$ \\
$\begin{array}{l}\text { Zaman harcattırıcılar } \\
\text { ve AGNO }\end{array}$ & 0,165 & 0,003 & $\begin{array}{l}\mathrm{P}<0,01 \text { olduğundan pozitif yönlü } \\
\text { anlamlı bir ilişki vardır }\end{array}$ \\
$\begin{array}{l}\text { Zaman yönetimi ve } \\
\text { AGNO }\end{array}$ & 0,196 & 0,001 & $\begin{array}{l}\mathrm{P}<0,01 \text { olduğundan pozitif yönlü } \\
\text { anlamlı bir ilişki vardır }\end{array}$ \\
\hline
\end{tabular}

Yapılan korelasyon analizi sonucunda, zaman yönetimi ile AGNO arasında ve zaman yönetiminin alt faktörleri ile AGNO ile arasında pozitif yönlü anlamlı bir ilişkinin var olduğu görülmektedir.

\subsection{Zaman Yönetiminin, AGNO Üzerindeki Etkisinin Araştırılmasına Yönelik Regresyon Analizi}

Korelasyon analizi sonucunda aralarında ilişki olduğu saptanan değişkenler, "Zaman yönetimi ve onun alt faktörleri AGNO üzerinde bir etkileme gücüne sahip midir?" sorusunun yanıtını almak için regresyon analizine tabi tutulmuşlardır. Yapılan regresyon analizinin sonuçları Tablo 8 'deki gibi verilmektedir.

Tablo 8. Zaman yönetimi ve alt faktörlerinin AGNO üzerindeki etkisini belirlemeye yönelik regresyon analizi

\begin{tabular}{lcccc}
\hline & \multicolumn{5}{c}{ Bağımlı Değişken ( AGNO ) } \\
Bağımsız Değişkenler & $R 2$ & $F$ & Sig & $\begin{array}{l}\text { B (Sabit) ve } \\
\text { B (Değişken) }\end{array}$ \\
\hline Zaman Planlaması (ZP) & 0,025 & 7,069 & 0,008 & 1,535 ve 0,312 \\
Zaman Tutumu (ZT) & 0,016 & 4,318 & 0,039 & 1,798 ve 0,212 \\
Zaman Harcattırıcılar (ZH) & 0,027 & 7,632 & 0,006 & 1,481 ve 0,296 \\
$\begin{array}{l}\text { Zaman Yönetimi } \\
\text { (ZP+ZT+ZH) }\end{array}$ & 0,038 & 10,869 & 0,001 & 1,034 ve 0,472 \\
\hline
\end{tabular}


Yapılan regresyon analizlerine ilişkin modeller aşağıdaki gibi gösterilebilir.

$$
\begin{aligned}
& \text { AGNO }=1,535+0,312 \times \text { Zaman Planlaması } \\
& \text { AGNO }=1,798+0,212 \times \text { Zaman Tutumu } \\
& \text { AGNO }=1,481+0,296 \times \text { Zaman Harcattırıcılar } \\
& \text { AGNO }=1,034+0,472 \times \text { Zaman Yönetimi }
\end{aligned}
$$

AGNO'daki değişikliği açıklama noktasında en büyük açıklama gücüne sahip olan bağımsız değişkenin zaman harcattırıcılar, en düşük açıklama gücüne sahip olan bağımsız değişkenin ise zaman tutumu olduğu görülmektedir. Zaman yönetiminin ise AGNO'daki değişikliğin yaklaşı \% 4'ünü açıklama gücüne sahip olduğu görülmektedir. Ancak gerek zaman yönetiminin gerekse alt faktörlerinin AGNO'daki değişikliği açıklama gücü düşüktür.

\section{SONUÇ}

$\mathrm{Bu}$ araştırmada öğrencilerin zaman yönetimi becerileri ile akademik başarıları arasındaki ilişki ortaya konmaya çalışılmıştır. Araştırma sonucunda, cinsiyet değişkenine göre, kadın öğrencilerin gerek AGNO'ları gerekse zaman yönetiminin tüm boyutlarında ortalamalarının erkeklerden yüksek çıktığı bulgusuna ulaşılmıştır. Kadın öğrenciler, zamanı planlamaları, zamana karşı tutumları ve zaman tuzaklarına yakalanmamaları açısından erkek öğrencilerden daha iyi durumdadırlar.

Zaman yönetiminin tüm boyutları ile AGNO'lar arasında anlamlı bir ilişkinin var olduğu görülmüsstür. Bu ilişki düşük bir düzeyde fakat anlamlıdır. $\mathrm{Bu}$ ilişkinin düşük olması çeşitli nedenlerle ilişkilendirilebilir. Bunlardan bir tanesi öğrencilerin zaman yönetimine ilişkin algılamaları ve davranışları benzer olsa bile, ders çalışma biçimleri, çalışma ortamları, arkadaşları, algılama seviyeleri, sayısal ya da sözel becerileri, maddi imkanları gibi bir çok konuda bireysel bir takım farklılıklara sahip oldukları gerçeğidir. Bu yönüyle konunun farklı değişkenler göz önüne alınarak araştırılmasına ihtiyaç olduğu söylenebilir.

Öğrencilerin, seçtikleri bölüm, üniversiteye kendi istekleri ya da ailelerinin zorlamasiyla gelip gelmedikleri, üniversitelerinden duydukları memnuniyet gibi konuların da farklı bir açıdan başarı üzerinde ekili olduğu söylenebilir. Amacın başkası tarafindan belirlendiği ya da yeterince öğrenci 
tarafindan belirlenmediği durumlar, iyi bir ortalamaya sahip olsalar dahi yüksek puanlı üniversitelerin sıradan ortalamalara sahip öğrencileriyle dahi rekabet edemeyecekleri algısı, zamanın yönetilmesi konusunda öğrencilerin yeterli istekliliği göstermemesine neden olabilmektedir.

Üniversiteden yüksek notlarla mezun oldukları halde işsiz kalan bireylerin varlı̆̆g, üniversitede okuyan öğrencilerin nazarında akademik başarının önemini düşürme potansiyeline sahip olabilir. Öğrencilerin eğitim aldıkları bölümle ilişkili olmayan kamu görevlerine (örn. polislik, askerlik) girmeyi daha kolay görmelerinin ve bu görevlere yerleşmede diploma üzerinde yazan başarı ortalamasına gereken hassasiyetle yaklaşılmamasının, öğrencilerin üniversiteye girmelerinden itibaren bu amaç doğrultusunda yüksek bir başarıyı arzulamaktan uzaklaşmalarına, sadece diplomalarını alacakları tarihe kadar asgari başarıyı elde etmeye odaklanmalarına neden olabildiği göz ardı edilmemelidir.

Erkek öğrencilerin, içinde yaşadıkları kültüründe bir parçası olan, erkeğin aile reisi olarak aileye bakma yükümlülüğü dayatması altında bu davranışları sergilemesi kadınlara göre daha kolay olacaktır. Kadınlar ise tam tersi bir biçimde eğitim ve bu alanda elde edecekleri yüksek başarı ile hayatlarına yön verme özgürlügünü daha fazla elde edecekleri düşüncesiyle başarıyı erkeklere göre daha fazla arayacaklardır.

Kültürel olarak kadercilik olarak ifade ettiğimiz olgunun, üniversite hayatından önce bireyinde içinde yer aldığı toplumun bir gerçeği olduğu da göz önünde bulundurulmalıdır. Alışkanlıkların değiştirilmesi,dönüştürülmesi ancak bir ihtiyacı karşılayan fayda ile ilişkilendirildiğinde anlamlı olacaktır. $\mathrm{Bu}$ faydanın birey tarafından anlaşılması zaman yönetimi alışkanlığının edinilmesini kolaylaştırabilecektir.

Akademik başarı ve başarının bir sonucu olan yüksek bir mezuniyet ortalaması öğrencilerin 4 yıllık bir eğitim sürecinin sonunda elde ettikleri bir çıktıdır. Öğrencilerin 4 yıllık eğitim süresi ve bu sürecin sonunda elde edeceği çıktılarla ilgili bir fayda maliyet analizi yapmaları, öğrencileri, daha kısa vadede, daha az maliyetle ve daha az fayda sağlayacak amaçları gerçekleştirmeye sevk edebilecektir. Başarının uzun vadede gelmesi, getirisinin bugünden görülememesi, bugün itibariyle öğrenciler gözünde getirisinin yeterli olmadığı algısı (yeni mezunların iş bulamaması, iş bulma 
süreleri, iyi ücretler kazanamamaları vb.) öğrencileri bu yola sevk eden önemli bir psikolojik zorluktur.

Hopa ilçesinin küçük bir ilçe olması ve büyük şehirlere kıyasla hayatın yavaş akması, ya da hayatın akışını etkileyen yaşamsal zorlukların azlığı, zamanın yönetilmesiyle ilgili bir ihtiyacın hissedilmesini zorlaştırmaktadır. $\mathrm{Bu}$ ihtiyacın hissedilmemesi, çalışma yaşamının temel ölçütlerinden birisi olan zaman ve zamanın yönetilmesi gibi bir konuda öğrencilerin eksik bir deneyime sahip olarak zorlanmaları sonucunu doğurabilmektedir.

\section{KAYNAKLAR}

Akgemci, T., Çelik, A., Aydoğan, E., Akatay, A., (2003). Zaman Yönetimi ve Yönetsel Zamanda Etkinlik, (Editör: M. Şerif Şimşek, Adnan Çelik), Ankara: Gazi Kitabevi.

Alay, S., Koçak S., (2002). Validity and reliability of time management questionnaire. Hacettepe Üniversitesi Eğitim Fakültesi Dergisi, 22, 9 13.

Alay, S., Koçak S., (2003). Üniversite Öğrencilerinin Zaman Yönetimleri İle Akademik Başarıları Arasındaki İlişki. Kuram ve Uygulamada Ĕgitim Yönetimi Dergisi, 35, 326-335.

Bond, M. J., \& Feather, N. (1988). Some Correlates of Structure and Purpose in the Use of Time. Journal of Personality and Social Psychology, 55, 321-329.

Brittain, V., Hull, T., (2003). Paralegal Handbook, Clifton Park, NY : Thomson/Delmar Learning, Australia,

Britton, B. K., ve Tesser, A., (1991). Effects of Time-Management Practices on College Grades, Journal of Educational Psychology, 83(3), 405410.

Candaş, D. (2002). Belleğimizde Sakladığımız Zaman. Bilim ve Teknik, 418, $50-53$.

Claessens,B.J.C., ERDE, W., RUTTE,C. \& ROE, R. .(2007). A review of the time management literature, Personnel Review, 36, 255-276

Cüceloğlu, D. (1999). İnsan ve davranışı: Psikolojinin temel kavramları, Remzi Kitabevi 
Deb, S. (2001), Contemporary Issues on Management, Atlantic Publishers and Distributers, New Delhi.

Durmaz, M., Hüseyinli,T., ve Güçlü,C.,(2016). Zaman Yönetimi Becerileri ile Akademik Başarı arasındaki İlişki, Insan ve Toplum Bilimleri Araştırmaları Dergisi, 5 (7), pp.2291-2303.

Elias, N. (2000). Zaman üzerine. (Çev: Veysel Atayman). İstanbul: Ayrıntı Yayınları.

Francis-Smythe J. A., Robertson I. T. (1999). On the relationship between time management and time estimation. British Journal of Psychology, 90, 333-347.

Green, P., Skinner, D.(2005). Does time management training work? An evaluation, International Journal of Training and Development, 9 (2), 124-139.

Güçlü, N. (2001). Zaman yönetimi, Kuram ve Uygulamada Eğitim Yönetimi Dergisi, 25, 87-106.

Gümüş, M. ( 1999). Yönetimde Başarı İçin Altın Kurallar. İstanbul: Alfa Yayın, No: 271.

http://www.tdk.gov.tr

Josephs, R. (1996), Zaman Yönetimi, 2. Baskı, (Çev: Özlem Koşar), İstanbul: Epsilon Yayınları.

Kaufman-Scarborough, C. and Lindquist, J.D. (1999), Time management and polychronicity: comparisons, contrasts, and insights for the workplace, Journal of Managerial Psychology, 14,288-312.

Kelly, W. E. (2002), Harnessing the River of Time: A Theoretical Framework of Time Use Efficiency with Suggestions for Counselors, Journal of Employment Counseling, 39(Mart), 12-22.

Konig, C. J. \& Kleinmann M., (2007). Time Management Problems and Discounted Utility, The Journal of Psychology, 141(3), 321-334.

Lay, C. H., \& Schouwenburg, H. C. (1993). Trait procrastination, time management, and academic behavior. Journal of Social Behavior and Personality, 8, 647-662.

Macan, T.H. (1994). Time Management: Test of a Process Model, Journal of Applied Psychology, 79 (3), 381-391. 
Mackenzie, A. (1987). Zaman Tuzağı. (Çev. Yakut Güneri), İstanbul: İlgi Yayınc1lik.

Oshagbemi, T; (1995). Management Development and Managers' use of their time, Journal of Management Devolopment, 14(8), 19-34.

Passig, D. (2005). Future-time-span as a Cognitive Skill in Future Studies. Futures Research Quarterly, 19 (4), 27-47.

Reunanen T., (2016). Chronos and Kairos. Jussi KANTOLA içinde, Understanding and Managing Time Organizational Resource Management, Theories, Methodologies \& Applications, (ss.111-120), CRC Press, Taylor \& Francis Group 2016

Reunanen, T., (2015).Human factor in time management, Procedia Manufacturing, Vol. 3, 709-716.

Sabuncuoğlu, Z., Paşa, M., (2002). Zaman Yönetimi, Bursa:Ezgi Kitapevi.

Shahani, C., Weiner, R.\& Streit, M. K. (1993). An investigation of the dispositional nature of the time management construct, Anxiety, Stress, and Coping, 6, 231-243.

Tanrı̈ğen, A., \& İşcan, S. (2009). Time management skills of Pamukkale University students and their effects on academic achievement. Eğitim Araştırmalart-Eurasian Journal of Educational Research, 35, 93-108.

Tutar, H. (Ed.) (2003). Zaman Yönetimi, Ankara: Nobel Yayın Dağıtım.

Yavaş, Ü., Öztürk, G. Açıkel, C. H., Özer, M.,(2012). Tıp Fakültesi Öğrencilerinin Zaman Yönetimi Becerilerinin Değerlendirilmesi [Evaluation of Medical Faculty Students' Time Management Skills] TAF Prev Med Bull, 11(1), 5-10.

Yılmaz, İ.,Yoncalık, O., Bektaş, F., (2010). Zaman Yönetimi Davranışı ile Akademik Başarı Arasındaki İlişki, e-Journal of New World Sciences Academy Sports Sciences, 5(3), 187-194. 